\title{
new community
}

Journal of the Commission for Racial Equality

\author{
Editor: Sheila Patterson
}

For the facts on race and community relations in Britain

Volume IX No.1, Spring-Summer 1981

Unemployment, Prejudice and Social Policy

Shirley Williams on Unemployment

Professor Sheila Allen on Migrant Labour and Race

Colour: Associations, Symbolism and Categorisation

An Inquiry into the Pejorative Associations

of an English Word

Colour Symbolism and the Skin

Mixed Race Children and Racial Categorisation

Stop and Search, Cross-Cultural Counselling

Race Relations Training, The Irish in Britain

Subscriptions: $£ 6.00$ individual, $£ 8.00$ institutions from New Community Subscriptions

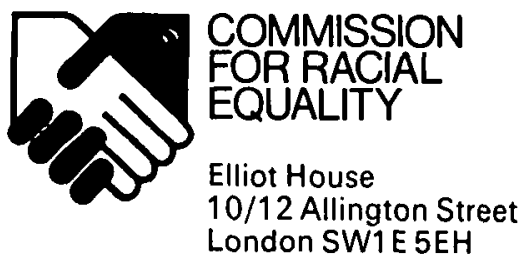




\section{SOCIAL ADMINISTRATION ASSOCIATION}

The Association exists for those whose work consists mainly of teaching or research in the fields of Social Administration and Social Policy. It was formed some years ago to enable staff from universities, polytechnics, technical and other colleges, independent and Government research organisations to meet and discuss matters of common interest.

The Association acts as a representative of its members and of Social Administration through contacts with the Social Science Research Council, the Council for National Academic Awards and the Business Education Council.

The Association has specialist groups which meet to discuss the teaching of social policy and public expenditure and social policy.

The Association holds an Annual Conference. The 1982 conference will be from 13 th to $15^{\text {th }}$ July in Leeds. The theme will be 'Politics and Social Policy'.

The current membership subscription is $£_{25.50}$ per calendar year; this includes the subscription to the Association's Journal, the Journal of Social Policy (four issues per year).

General enquiries should be addressed to Stephen Winyard,

Department of Social Policy and

Administration,

University of Leeds,

Leeds,

LS2 9JT

Enquiries about the 1982 conference should be addressed to

Joan Higgins,

Department of Sociology

and Social Administration,

University of Southampton,

Southampton $\mathrm{SO}_{9} \mathrm{NH}$.

Enquiries about membership should be

addressed to

John Morgan

Department of Social Administration,

University of Birmingham,

PO Box 363

Birmingham BI5 2TT 


\section{RICHARD TITMUSS PRIZE}

The Richard Titmuss Prize, established by the Journal of Social Policy and the Social Administration Association in memory of his unique contribution to the study of social policy, is awarded annually for an article on any subject within the general field of social policy. However, the competition is restricted to entrants under the age of thirtyfive.

The prize is $£_{100}$ and the prize article will be published in the Journal of Social Policy. In exceptional circumstances more than one prize may be awarded.

It is intended to announce the award of a prize each year, at the Annual Conference of the Social Administration Association, provided that an entry of sufficient merit has been received.

The article must be an original contribution, not hitherto published, and one which has not been awarded any other prize. It must not exceed 10,000 words in length. Anyone intending to submit work for consideration for the prize should first obtain details of the conditions of entry from the Editor, Journal of Social Policy, PSSRU, Cornwallis Building, The University, Canterbury, Kent, $\mathrm{CT}_{2}{ }_{7} \mathrm{NF}$.

The closing date for entries is 1 April each year. 


\section{Journal of Social Policy}

\section{Notes for Contributors}

1. All contributions and correspondence should be sent to: The Editor, Journal of Social Policy, PSSRU, Cornwallis Building, The University, Canterbury, Kent, CT2 7NF. All books for review should be sent to: The Review Editor, Journal of Social Policy, Department of Sociology and Social Administration, University of Southampton, Highfield, Southampton $\mathrm{SO} 95 \mathrm{NH}$.

2. Articles should generally contain between 5,000 and 10,000 words including footnotes, although longer or shorter articles may be accepted by arrangement with the editor. Short articles stand a better chance of early publication.

3. Submission of an article is taken to imply that it has not previously been published, or is not being considered for publication elsewhere. If an author is publishing a related article elsewhere, this fact should be stated.

4. Contributions (articles, review articles, reviews) should be clearly typed on one side of the paper only using a conventional size of paper, preferably A4. All material should be typed double-spaced with generous margins. Contributors should send two copies and keep one copy of the typescript for correcting proofs.

5. Contributions should be accompanied by an abstract of between one and two hundred words, and a title page providing information about the position/s held by the author/s and giving full details of any acknowledgements.

6. Manuscripts will not be accepted for publication unless they conform to the usual journal style. Contributors are advised to look at the latest issue of the journal for general guidance, although a brief style sheet is available from the editor upon request. Particular attention should be made to the journal requirements about references and tables.

7. Notes should not contain bibliographical references: these should be built into the text and the Harvard (author/date) system used. Such notes as are essential should be referred to in numerical order throughout the text and the numbers shown as superscript. Notes and bibliographical references should be typed (double-spaced) as separate sections at the end of the article.

8. Tables should be clearly laid out and designed to fit on to a page $234 \mathrm{~mm} \times$ $155 \mathrm{~mm}$. Vertical lines between columns should be omitted, and horizontal lines limited to the top and bottom of the table, with an additional one below the column headings. Totals and percentages should be labelled, and units identified.

9. First proofs may be read and corrected by contributors provided that they can give the editor an address through which they can be reached without delay and can guarantee to return the corrected proofs to the editor, by airmail where appropriate, within seven days of receiving them. The master proof will always be sent direct to the editor by the printer; contributors will receive duplicates.

10. Authors of articles and review articles (but not book reviews) receive twentyfive free offprints. Additional copies may be bought if ordered at proof stage.

11. Contributors of accepted articles will be asked to assign their copyright, on certain conditions, to Cambridge University Press, to help protect their material, particularly in the USA 
TABLE OF CONTENTS

EDITORIAL

\section{ARTICLES}

ST UART S. BL UME: Explanation and Social Policy: 'The' Problem of Social Inequalities in Health

RICHARD DISNEY: Theorising the Welfare State: The Case of Unemployment Insurance in Britain

MARIA BRENTON: Changing Relationships in Dutch Social Services

POLICY REVIEW ARTICLE

MIRIAM E. DAVID: Day Care Policies and Parenting

Kathleen M. Slack: Social Administration Digest

\section{BOOK REVIEWS}

N. Timms (ed.): Social Welfare: Why and How? (C. McCreadie)

R. Plant, H. Lesser \& P. Taylor-Gooby: Political Philosophy and Social Welfare (C. McCreadie)

F. Field: Inequality in Britain (N. Bosanquet)

P. Taylor-Gooby \& J. Dale: Social Theory and Social Welfare (A. Weale)

A. McAuley: Women's Work and Wages in the Soviet Union (F. Millard)

J. Brine, M. Perrie \& A. Sutton (eds): Home, School and Leisure in the Soviet Union (F. Millard)

D. J. Smith: Overseas Doctors in the NHS (S. Haywood)

B. Glastonbury, D. M. Cooper \& P. Hawkins: Social Work in Conflict (R. Hadley)

G. H. Mooney, E. R. Russell \& R. D. Weir: Choices for Health Care (R. Cullen)

K. Judge (ed.): Pricing the Social Services (R. Cullen)

J. Leach \& J. Wing: Helping Destitute Men (J. Stewart)

T. \& P. Hall: Part-time Social Work (O. Stevenson)

D. Watson: Caring for Strangers (R. Plant)

J. Bradshaw \& D. Piachaud: Child Support in the European Community (E. James)

G. Rees \& T. L. Rees: Poverty and Social Inequality in Wales (L. Moseley)

F. Sandbach: Environment, Ideology and Policy (M. Harloe)

M. Boddy: The Building Societies (M. Harloe)

A. Ravetz: Remaking Cities (J. Cullingworth)

J. E. Bradley: The Housing Action Area Approach (J. English)

M. Swenarton: Homes Fit for Heroes (A. Deacon)

C. Hakim: Occupational Segregation (J. Clark)

G. P. Marshall: Social Goals and Economic Perspectives (A. Maynard)

K. Judge \& J. Matthews: Charging for Social Care (H. Glennerster)

R. Illsley: Professional or Public Health? (R. Klein)

R. A. Chapman \& J. R. Greenaway: The Dynamics of Administrative Reform (J. Dearlove) 137

G. Rhodes: Inspectorates in British Government (D. Hill)

M. Hill: Understanding Social Policy (G. Smith)

D. C. Anderson (ed.): The Ignorance of Social Intervention (C. Bryant)

Cambridge University Press

The Pitt Building, Trumpington Street, Cambridge CB2 1RP

32 East 57th Street, New York, N.Y. 10022

Printed in Great Britain by

Western Printing Services Ltd, Bristol 